Review

\title{
Fluorescence in Situ Hybridization (FISH) for Detecting Anaplastic Lymphoma Kinase (ALK) Rearrangement in Lung Cancer: Clinically Relevant Technical Aspects
}

\author{
Zhenya Tang ${ }^{1, *}$, Lu Wang ${ }^{2}$, Guilin Tang ${ }^{1}$ and L. Jeffrey Medeiros ${ }^{1}$ \\ 1 Department of Hematopathogy/Clinical Cytogenetics Laboratory, the University of Texas MD Anderson \\ Cancer Center, Houston, TX 77030, USA \\ 2 Department of Pathology, St. Jude Children's Research Hospital, Memphis, TN 38105, USA \\ * Correspondence: ztang@mdanderson.org; Tel.: +713-563-4369; Fax: +713-563-3166
}

Received: 30 June 2019; Accepted: 11 August 2019; Published: 13 August 2019

\begin{abstract}
In 2011, the Vysis Break Apart ALK fluorescence in situ hybridization (FISH) assay was approved by the United States Food and Drug Administration as a companion diagnostic for detecting $A L K$ rearrangement in lung cancer patients who may benefit from treatment of tyrosine kinase inhibitor therapy. This assay is the current "gold standard". According to updated ALK testing guidelines from the College of American Pathologists, the International Association for the Study of Lung Cancer and the Association for Molecular Pathology published in 2018, ALK immunohistochemistry is formally an alternative to ALK FISH, and simultaneous detection of multiple hot spots, including, at least, $A L K, R O S 1, R E T, M E T, E R B B 2, B R A F$ and KRAS genes is also recommended while performing next generation sequencing (NGS)-based testing. Therefore, ALK status in a specimen can be tested by different methods and platforms, even in the same institution or laboratory. In this review, we discuss several clinically relevant technical aspects of ALK FISH, including pros and cons of the unique two-step (50- to 100-cell) analysis approach employed in the Vysis Break Apart ALK FISH assay, including: the preset cutoff value of $\geq 15 \%$ for a positive result; technical aspects and biology of discordant results obtained by different methods; and incidental findings, such as $A L K$ copy number gain or amplification and co-existent driver mutations. These issues have practical implications for ALK testing in the clinical laboratory following the updated guidelines.
\end{abstract}

Keywords: ALK; fluorescence in situ hybridization (FISH); immunohistochemistry (IHC); next generation sequencing (NGS); cutoff value; discordant result; incidental finding

\section{Introduction}

Lung cancer is the most common cause of cancer-related deaths in the United States [1] and in many other countries [2,3]. An estimated 142,670 deaths from lung cancer will occur in 2019 in the United Sates [1] and over 1.7 million patients died of lung cancer worldwide in 2018 [2,3]. The development of molecularly targeted therapeutics, such as tyrosine kinase inhibitors (TKI) directed against epidermal growth factor receptor (EGFR) mutations (e.g., erlotinib, gefibinib and osimertinib) and anaplastic large-cell lymphoma kinase $(A L K)$ rearrangement (e.g., crizotinib, certinib, alectinib and brigatinib), has improved outcomes of lung cancer patients with these mutation [4-7]. However, only $3-7 \%$ of non-small cell lung cancers (NSCLC) carry ALK rearrangement, which is mostly driven by an in-frame fusion of echinoderm microtubule associated protein like 4 (EML4) and ALK, both located on 2p23 and approximately $12 \mathrm{Mb}$ apart. Patients with lung cancer that carry EML4-ALK fusion respond to tyrosine kinase inhibitors (TKI), such as crizotinib, and therefore unambiguous detection of $A L K$ 
status in a lung cancer specimen is critical for a treatment decision and predicts the outcome of the affected patient.

Crizotinib was the first TKI approved by the United States Food and Drug Administration (FDA) as a targeted therapy for patients with ALK rearranged NSCLC in 2011. Simultaneously, the FDA approved the Vysis ALK Break Apart fluorescence in situ hybridization (FISH) Probe Kit (Abbott Molecular) as a companion diagnostic test to identify the patients most likely to benefit from crizotinib therapy. This commercial kit has been considered to be a "gold standard" for clinical testing for ALK rearrangements, but there are challenges raised about this assay regarding its analytical sensitivity and specificity, accuracy of test results, and high expense as a screening test, as well as the development of other methods/technologies, such as immunohistochemistry (IHC) and next generation sequencing (NGS) that are currently available to assess ALK status.

In this review, we attempt to concisely discuss several clinically relevant technical issues that are sometimes troublesome for clinical laboratories performing this test, including: the uncommon two-step (50- to 100-cell) analysis approach; the 15\% cutoff value for a positivity; discordant results obtained by different methods/technologies; and incidental findings, such as ALK copy number gain and amplification or coexistent driver mutations. We also propose an algorithm for $A L K$ testing in a clinical laboratory.

\subsection{The Uncommon Two-Step (50- To 100-Cell) Analysis Approach}

The FDA-approved Vysis ALK Break Apart FISH probe consists of a $3^{\prime} A L K$ probe of approximately $300 \mathrm{~kb}$ labeled in SpectrumOrange and a $5^{\prime} A L K$ probe of about $442 \mathrm{~kb}$ labeled in SpectrumGreen. The $3^{\prime} A L K$ and $5^{\prime} A L K$ probes are located centromerically and telomerically to the ALK breakpoint, respectively [8]. According to the Vysis ALK Break Apart FISH evaluation guide for NSCLC tissue specimens and the summary of safety and effectiveness data provided by Abbott Molecular [8,9], the protocol is a two-step (50- to 100-cell) analysis approach (Figure 1), as follows:

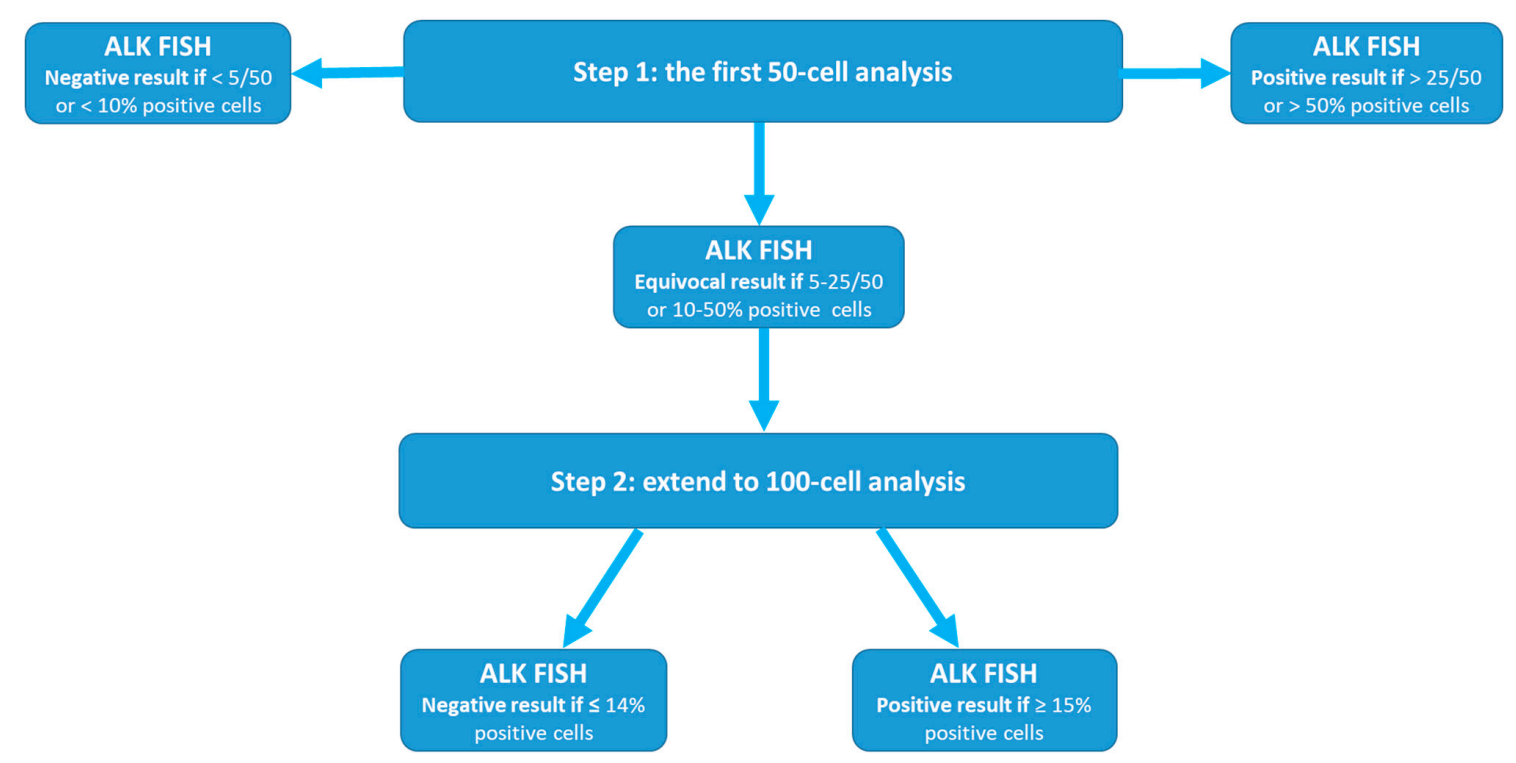

Figure 1. Schematically illustration of the two-step (50- to 100-cell) analysis approach of the Vysis ALK (anaplastic lymphoma kinase) Break Apart FISH (fluorescence in situ hybridization).

Step 1: After hybridization and location of target area for analysis, 50 nuclei are counted initially and test results are categorized as follows: 1$)$. Negative if $<5$ cells $(<5 / 50$ or $<10 \%)$ have positive signals; 2 ). Positive if $>25$ cells ( $>25 / 50$ or $>50 \%$ ) are positive; 3 ). Equivocal if 5 to 25 cells (or $10 \%$ to $50 \%$ ) are tested with positive signal(s). 
Step 2: for all samples with an equivocal result, a second reader needs to evaluate an additional 50 nuclei and the results for all 100 nuclei by the first and second readers are added together and a percentage is calculated [10]. 1). Negative if $<15 \%(<15 / 100)$ nuclei have positive signals; and 2$)$. Positive if $\geq 15 \%$ ( $\geq 15 / 100)$ nuclei have positive signals.

This uncommon two-step approach is different from the current American College of Medical Genetics and Genomics (ACMGG) technical standards and guidelines for FISH analysis [11] where usually a one-step analysis of 200-cells for both liquid (bone marrow, peripheral blood, etc.) and tissue specimens is recommended. Although the ACMGG has stated the analytical criteria for FDA-approved probes supersede the general rules listed in its standard and guidelines [11], we believe that this uncommon ALK FISH test approach has advantages. The first of these is the unavailability of standards and guidelines from a professional and/or scientific society for tissue FISH testing, or more specifically for ALK FISH testing in NSCLC, and the approval of this assay by the FDA. In 2011, the ACMGG FISH guidelines [12] were applied only for constitutional disorders and the Association for Molecular Pathology (AMP)/ACMGG guidance only for hematologic disorders (only liquid specimens) [13]. Secondly, previous studies, especially the first pivotal clinical trials leading to the FDA approval of crizotinib [14,15], were successful in identifying patients for targeted therapy by adopting this approach. Third, a 50-cell or 100-cell analysis is obviously more cost-effective than a 200-cell analysis, providing the lower counts come to the same conclusion as a 200-cell count for the same specimen. Lastly, theoretically the analysis of more cells may "dilute" the percentage of positivity if the number of positive cells is actually limited in a specimen.

Camidge et al. [16] has shown that analysis of $\geq 60$ cells from $\geq 4$ selected tumor areas of a NSCLC specimen can reach $100 \%$ specificity and $100 \%$ of sensitivity for $A L K$ rearrangement testing, although the Vysis ALK Break Apart FISH probe set used in their study is slightly different for coverages of both $5^{\prime} A L K$ and $3^{\prime} A L K$ probe from the one approved by the FDA. These authors also emphasized that analysis of $\geq 60$ cells from $\geq 4$ selected tumor areas is considered as a minimum requirement for accurately testing the status of $A L K$ in NSCLC specimens. Therefore, this two-step approach seems to be rational and practical for clinical laboratory practice [17,18]: a 50-cell analysis (step 1) to identify specimens with high percentages of $A L K$ rearrangements ( $>25 / 50$ or $>50 \%$ ) and then another 50-cell analysis (step 2) for specimens with equivocal results. However, there are apparent drawbacks of this uncommon two-step approach. First, specimens with a definite positive result at the first step $(>25 / 50$ or $>50 \%$ ) and specimen tested as positive during the second step have been analyzed differently for the total cell number and tumor areas. The accuracy of percentages of positive cells in these specimens can fluctuate when they are analyzed the same way (e.g., 200-cell read). Therefore, categorizing NSCLC patients into "high ALK rearranged" and "low ALK rearranged" based on the percentages by this approach and correlating with therapy response and clinical outcomes should be interpreted cautiously $[19,20]$. Secondly, specimens with an equivocal result with $15(\geq 15 / 50)$ to $25(\leq 25 / 50)$ positive cells in the first step will be definitely considered as positive ( $\geq 15 / 100$ or $\geq 15 \%)$, no matter whether any additional positive cells will be identified in the second step. The rationale for the more extensive analysis in these specimens is not explained or understood [8,9]. A more cost-effective way could be to count to 100 cells only for those specimen with 5 to 14 positive cells in the first step.

\subsection{The Cutoff Value of $\geq 15 / 100$ or $\geq 15 \%$ for a Positive Test Result}

Although the $\geq 15 \%$ result has been widely applied for clinical decisions, including patient selection for targeted therapy and the prediction of treatment response, this cutoff value for a positive $A L K$ rearrangement in a NSCLC specimen was initially not defined by a clinical end point. Instead, it was established based on an analytical assessment of the background signals ("background noise") [16,21,22]. Shaw et al. [21] and Rodig et al. [22] first applied this value as a cutoff for a positive ALK rearrangement in their studies, but it is not disclosed how this cutoff value was established. Camidge et al. [16] reported the validation of this cutoff value in detail. In their report, 17 previously tested ALK-positive $(\mathrm{ALK}+)$ and 15 ALK-negative (ALK-) NSCLC specimens were thoroughly analyzed to document ALK 
FISH signal pattern(s) in all types of cells of each specimen, including ALK+ tumor cells, ALK- tumor cells and their adjacent normal areas. An average of 53.8\% (range 22.3-86.6\%) of ALK+ tumor cells, $6 \%$ (range 3.5-9.5\%) of ALK - tumor cells, 6.8\% (range 2.1-11.1\%) of adjacent non-tumor cells in ALK+ specimens, and $5.3 \%$ (range $0.7-11.2 \%$ ) of adjacent non-tumor cells in ALK- specimens exhibited positive ALK FISH signal patterns. Therefore, a non-overlapping area of $12 \%$ to $21 \%$ positivity exists between the ALK+ tumor cells and background noise (up to $11 \%$ of positivity obtained from both the ALK- tumor cells and non-tumor cells). The cutoff value of $\geq 15 \%$ falls into this non-overlapping area and is thought to accurately distinguish true positive results from background noise caused by assay variability. This cutoff value was first adopted and correlated with response in the first crizotinib clinical trial [14,15].

Although it is currently widely applied in almost all clinical laboratories performing the Vysis ALK Break Apart FISH assay in the United States, the rationale of using this cutoff value has been challenged for at least three reasons:

1). This cutoff value is based on analysis of a limited number of NSCLC cases from a single institution [16]. All 13 ALK rearrangement positive cases included in the study showed definite positivity with high percentages of positive cells (e.g., $\geq 28 \%(13 / 13),>40 \%(11 / 13)$ and $>50 \%(9 / 13)$, respectively). No cases with a low number of positive cells (e.g., of $15-20 \%$ or even lower) was included. Interestingly, an Italian group [23] has validated the Vysis ALK Break Apart FISH probe and Dako ALK FISH Probe (now a subsidiary of Agilent, Santa Clara, CA) in a way similar to that recommended by the ACMGG [11] in 2015. The cutoff value that they have obtained from ALK negative panel of controls is $14.9 \%$ (mean $\pm 3 \mathrm{SD}$ ), almost as the same as that suggested by Abbott Molecular.

2). In all 13 positive cases, the $A L K$ rearrangement positive cells were distributed diffusely in all tumor areas tested, and the authors concluded that $A L K$ rearrangement is a diffuse event and the exact percentages of positive cells have little impact on outcome of ALK inhibitor treatment. The authors in another study further emphasized this observation [17]. However, more and more studies from other research groups have shown that a good response to crizotinib therapy was observed in some patients with NSCLC in which the percentage of $A L K$ rearrangement positive cells was $<15 \%$, indicating the existence of low levels of $A L K$ rearrangement and a focal, non-random distribution of positive cells in some NSCLC cases [24-28]. Soria et al. [19] performed a pooled meta- analysis of three large prospective crizotinib clinical trials for ALK positive NSCLC, designated as PROFILE 1005 [29], PROFILE 1007 [30] and PROFILE 1014 [31,32], to evaluate the relationship between the percentage of $A L K$ rearrangement positive cells and clinical outcomes or crizotinib responses. Among 1958 ALK positive patients enrolled in these trials, the median percentage of $A L K$ rearrangement positive cells was $58 \%$ (range $15-100 \%$ ). The objective crizotinib response rates were $56 \%(n=700 / 1246), 55 \%(n=725 / 1312)$ and $38 \%(n=25 / 66)$ for patients with $A L K$ rearrangement positive cells at a percentage of $>20 \%, \geq 15 \%$ and $15-19 \%$, respectively, implying that this $15 \%$ cut-off is clinically valid for diagnosis of $A L K$ rearrangement and patient selection for targeted therapy. At the same time, this meta-analysis also indicated that NSCLC patients with a higher percentage of $A L K$ rearrangement positive cells tend to respond better to the crizotinib therapy $[19,32]$.

3). Due to the two-step (50- to 100-cell) analysis approach, a range of equivocal results, also called "a safe zone for reporting", is eliminated. All cases with a percentage of $A L K$ rearrangement positive cells in the non-overlapping area of $12 \%$ to $21 \%$ can be extremely challenging to a laboratory director who is interpreting the results. Therefore, terms such as "borderline negative result (i.e., 10-14\%)" and "borderline positive result (i.e., 15-24\%)" have been suggested for further analysis of these cases by different methods/technologies (e.g., IHC, NGS or other methods) by others [19,33-35].

\subsection{Discrepancies among Results Obtained by Other Methods}

Prior to its approval as a companion diagnostic kit for testing ALK rearrangement in NSCLC, the ALK FISH test (Vysis ALK Break Apart FISH Probe Kit) was already being challenged by other methods/technologies, especially ALK immunohistochemistry (IHC) [21,22,36]. Others have reported 
that IHC is equally efficient, but more cost-effective than ALK FISH for screening ALK status in NSCLC specimens. However, discrepancies in results obtained by FISH and IHC, such as ALK FISH+/ALK IHC- or ALK FISH-/ALK IHC+, have been shown in some cases [24,37-40]. In the past decade, some new and better anti-ALK antibodies, as well as automation of IHC procedures, have been developed, and the new generation ALK IHC is considered as sensitive as ALK FISH for detecting ALK rearrangement [41-44]. In 2015, the FDA approved the VENTANA ALK (D5F3) CDx Assay (Roche Diagnostics) for a qualitative detection of ALK protein in NSCLC tissue specimens to identify patients eligible for treatment with crizotinib $[45,46]$.

Many groups have applied RT-PCR to detect ELM4-ALK fusion, the most common form of ALK rearrangement at RNA level [47-49]. According to their studies, the ELM4-ALK RT-PCR is both highly sensitive and specific for detection of $A L K$ rearrangement in NSCLC cases. The concordances between this method and ALK IHC or ALK FISH is approximately 95-100\% [47-50]. Next-generation sequencing (NGS) based methods are also becoming widely utilized in the detection of $A L K$ rearrangement. NGS-based methods have identified many ALK rearrangement positive cases with an atypical ALK FISH signal pattern and even in cases negative by ALK FISH [51-54]. However, NGS-based methods differ in targets (DNA or RNA), enrichment of target (amplicon-based or capture-based), tumor burden, analytical sensitivity and specificity $[55,56]$. Other methods/techniques, such as multiplexed PCR-based assay [57] and droplet digital PCR [58,59], as well as NanoString technology [60,61], also have been applied to detect $A L K$ rearrangement with success.

The discrepancies among results for $A L K$ rearrangement obtained by different methods have been reported in many studies, but the frequency of discrepancy has been variable. For example, von Laffert et al. [62] reported a complete concordance between ALK FISH, ALK IHC and RT-PCR in 15 NSCLC cases. In contrast, Matterson et al. [63] reported 64\% agreement between ALK FISH and ALK IHC (Ventana) (FISH+/IHC+ in nine cases; FISH+/IHC - in four cases; FISH-/IHC+ in five cases); $54 \%$ agreement between ALK FISH and ALK IHC (Dako) (FISH+/IHC+ in eight cases; FISH+/IHC - in five cases; FISH-/IHC+ in three cases); and 67\% agreement between ALK IHC (Ventana) and ALK IHC (Dako) (Ventana+/Dako+ in 10 cases; Ventana+/Dako- in four cases; Ventana-/Dako+ in one case), respectively. Interestingly, among six (3\%) cases with high ALK expression (mRNA level) tested by Affymetrix Gene Microarray, only three were positive by ALK FISH (two cases) or ALK IHC (Ventana). Gao and colleagues [64] also reported that the signal patterns in ALK FISH positive cases may be associated with the discordance with ALK IHC. In their study, all 27 ALK FISH positive samples with a split signal pattern (1R1G1F) were ALK IHC positive (100\% concordance), whereas three of 21 ALK FISH positive samples with a 5'ALK deletion signal pattern (1R1F) were ALK IHC negative (11\% discordance); two of these cases were negative ALK rearrangement as tested by a targeted NGS assay. Dacic et al. [64] observed an even larger discordance between ALK FISH and NGS testing, e.g., 20\% (3/15) for ALK FISH positive cases with a signal pattern of 1R1G1F; 60\% (6/10) for ALK FISH positive cases with a signal pattern of 1R1F; and 100\% (3/3) for ALK FISH positive cases with mixed signal patterns of 1R1G1F and 1R1F. The authors also stated that the signal patterns of ALK FISH showed no statistically significant association with crizotinib response, whereas NGS and ALK IHC positive cases were associated with a significantly higher response rate than NGS and ALK IHC negative cases $(p=0.016)$.

These discrepancies can be caused by multiple factors, such as technical and biological issues. Examples of technical issues include the analytical sensitivity and specificity of each method and pre-analytical factors such as the quality and preparation of tested specimens. Biologic issues include disproportion between $A L K$ rearrangement and $A L K$ transcription and/or ALK translation [65]; complex chromosomal aberrations involving $A L K$ rearrangement that are beyond FISH detection; different hetero- or homo-dimerization properties and stabilities of various chimeric ALK proteins; and ALK overexpression through other mechanisms, such as gene amplification or mutations [33,34]. It is beyond the scope of this review to discuss all these methods and their advantages and disadvantages in detail. A brief comparison of various methods used for ALK status evaluation is summarized in Table 1. 
In general, NSCLC specimens with either a "borderline negative" or a "borderline positive" ALK FISH result are more prone to have a discordant result obtained by other methods $[23,34,35,52,56,62,66,67]$. Specimens with borderline ALK FISH results need to be tested using another method to verify the suspected ALK alteration so that unnecessary targeted therapy can be avoided in patients with a false positive test result, and patients with a false negative result still have the opportunity to be properly treated.

Table 1. A brief comparison of methodologies being applied for evaluation of ALK status.

\begin{tabular}{cccc}
\hline Methodologies & Biology & Partner Gene Dependent? & $\begin{array}{c}\text { Potential False Negative Results } \\
\text { by Biology }\end{array}$ \\
\hline ALK FISH & $\begin{array}{c}\text { ALK gene rearrangement; } \\
\text { not for } A L K \text { mutation(s) }\end{array}$ & No & $\begin{array}{c}\text { ALK rearrangement driven by } \\
\text { cryptic and/or complex } \\
\text { chromosomal abnormalities } \\
\text { beyond FISH detection; abnormal } \\
\text { ALK status by mechanism(s) other } \\
\text { than } A L K \text { rearrangement }\end{array}$ \\
\hline ALK IHC & $\begin{array}{c}\text { Abnormal ALK protein } \\
\text { expression caused by } \\
\text { ALK rearrangement } \\
\text { and/or mutation(s) }\end{array}$ & $\begin{array}{c}\text { Yes (certain } A L K \\
\text { rearrangement may have } \\
\text { higher ALK protein expression } \\
\text { than the others) }\end{array}$ & $\begin{array}{c}\text { ALK rearrangement without high } \\
\text { level ALK protein expression }\end{array}$ \\
\hline RT-PCR & $\begin{array}{c}A L K \text { fusion transcripts } \\
\text { (RNA level); not for } A L K \\
\text { mutation(s) }\end{array}$ & Yes & $\begin{array}{c}\text { unknown partner gene(s)/fusion } \\
\text { points for } A L K \text { rearrangement }\end{array}$ \\
\hline $\begin{array}{c}\text { NGS-based targeted } \\
\text { DNA-seq }\end{array}$ & $\begin{array}{c}\text { ALK mutation(s) +/- } \\
\text { rearrangement; } \\
\text { depending on the } \\
\text { platform used }\end{array}$ & Not necessary & $\begin{array}{c}\text { variant fusion points outside the } \\
\text { targeted capture region }\end{array}$ \\
\hline $\begin{array}{c}\text { NGS-based targeted } \\
\text { RNA-seq }\end{array}$ & $\begin{array}{c}A L K \text { rearrangement }+/- \\
\text { mutation(s) }\end{array}$ & No & extremely rare \\
\hline
\end{tabular}

Abbreviations: ALK gene: anaplastic large-cell lymphoma kinase gene; FISH: fluorescence in situ hybridization; IHC: immunohistochemistry; NGS: next generation sequencing; RT-PCR: reverse transcription-polymerase chain reaction; seq: sequencing.

\subsection{Development of a Diagnostic Algorithm for Detection of ALK Status}

According to the updated molecular testing guidelines for the selection of lung cancer patients for treatment with targeted tyrosine kinase inhibitors recommended by the College of American Pathologists, the International Association for the Study of Lung Cancer and the Association for Molecular Pathology in 2017 [68], as well as the FDA having approved the VENTANA ALK (D5F3) CDx Assay (Roche Diagnostics) for a qualitative detection of ALK protein in NSCLC tissue specimens, both ALK FISH and the ALK IHC are considered as the first line methods for $A L K$ rearrangement testing. The guidelines also state that there is no apparent superiority of ALK FISH over the ALK IHC or vice versa, implying that either one these tests can be performed currently. The guidelines also state that a borderline result by the ALK FISH and weak staining by the ALK IHC can be extremely challenging to interpret. In this circumstance, the guidelines emphasize that specimens with discrepancies, either ALK FISH+/ALK IHC - or ALK FISH-/ALK IHC+, should be further tested by another validated method, such as RT-PCR and NGS [68]. Although there is no NGS-based assay approved by the FDA as a first line method for determining ALK status yet, this powerful methodology, also called massively parallel sequencing, has been changing the diagnostic field dramatically, in both lung cancer and all other diseases. Generally, the capture-based DNA or RNA NGS assay is preferred to the amplicon-based NGS assays of DNA for their coverages of variant ALK fusions [68]. It has been speculated that NGS assays will become first line of methods for ALK status testing, together with testing many other mutations in lung cancer. The RT-PCR assay is mainly a standard practice for determining ALK status in many other countries $[47,69,70]$.

Therefore, laboratories providing ALK testing using one or more of the methods mentioned above need to develop a diagnostic algorithm based on the availability, accessibility, cost-effectiveness and 
on-site validation. For example, either the FDA-approved ALK FISH or ALK IHC can be the main methodology. If a "borderline" result is obtained in a specimen, a reflex test should be performed. For cases with discrepant results obtained by two methods, a third methodology, if available, should be applied, so that a clear result can be obtained for each specimen and the possibility of false positive or false negative results can be maximally reduced or even eliminated [69,71,72]. As an example, a proposed testing algorithm using the ALK FISH as the first line method and ALK IHC and NGS as the confirmatory test is illustrated (Figure 2). This can be modified according to the landscape and practical implementation issues in each laboratory.

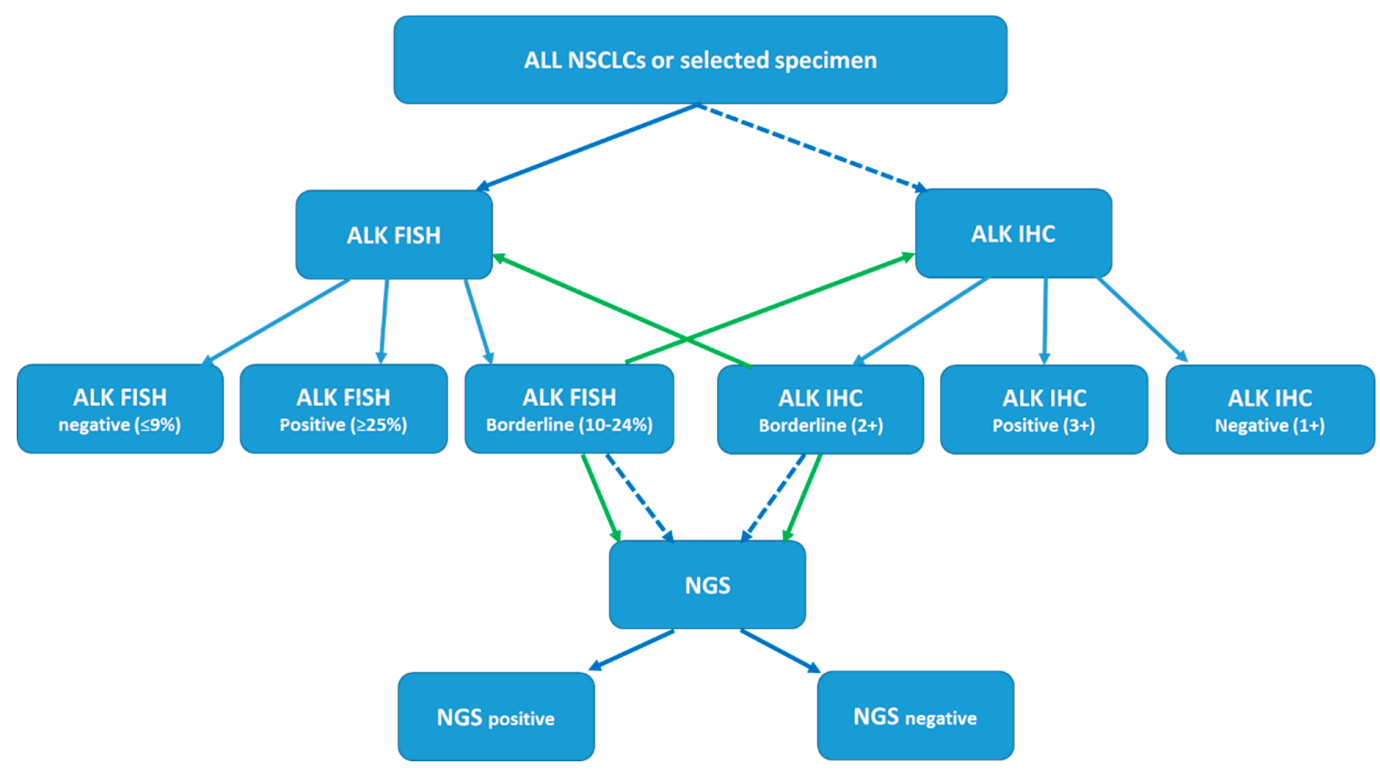

Figure 2. Proposed diagnostic algorithm for ALK status testing in lung cancer. For example, a specimen can be tested with ALK FISH (or ALK IHC) first. If a borderline result (either borderline negative or borderline positive) is obtained, the sample will be further tested with ALK IHC (or ALK FISH). If the ALK status is still uncertain, then targeted RNA-seq is applied and the final ALK status is determined based on the NGS result. For cases with discrepant results obtained by two methods, a third methodology, if available, should be applied to clarify the discrepancy. Solid blue arrow: proposed primary test methodology or predicted test results. Solid green arrow: proposed reflex test(s). Dashed blue arrow: alternative test methodology.

\subsection{Incidental Findings during ALK FISH Testing}

\subsubsection{ALK Gene Copy Number Gain/Amplification}

$A L K$ gene copy number gains ( $3-5$ copies/cell), especially $A L K$ gene amplification ( $>6$ copies/cell and/or clusters of signals) (Figure 3 ) are well studied in other types of cancer, i.e., neuroblastoma, and are generally considered to be associated with aggressive tumor behavior and poorer outcomes [73]. In fact, $A L K$ amplification is frequently detected in NSCLC and is more frequent than $A L K$ rearrangement. In a study of 107 NSCLC cases reported by Salido et al. [74], only three (3\%) cases exhibited ALK rearrangement, but $11(10 \%)$ and $68(63 \%)$ cases exhibited $A L K$ amplification and copy number gains, respectively. In addition to the ALK break-apart probe, the authors also included CEP2 (a centromeric alpha-satellite probe specific for chromosome 2) in the FISH test to distinguish ALK gains/amplification from polysomy of chromosome 2. Interestingly, only two cases with $A L K$ rearrangement were ALK-IHC+, whereas all other cases, including one case with $A L K$ rearrangement and all 11 cases with ALK amplification were ALK IHC-. Preusser et al. [75] observed a similar frequency of $A L K$ amplification, but also noticed that two cases with brain metastasis exhibited co-existent $A L K$ rearrangement and $A L K$ amplification in their study. The FDA-approved Vysis Break Apart ALK FISH 
probe does not include a control probe such as the CEP2 probe, but it can reflect the copy number of $A L K$ in each specimen (Figure 3). Camidge et al. [17,18] reported that $19 \%$ of $A L K$ rearrangement positive and $62 \%$ of $A L K$ rearrangement negative NSCLC cases exhibited an increased ALK copy number ( $>3$ copies per cell in $>40 \%$ of cells). Peretti et al. [76] reported that ALK copy number gain/amplification is very common in smoker/former smoker compared to non-smoker NSCLC patients ( $74.2 \%$ versus $20.4 \%$, which might provide a certain indication of genomic instability. Although the relationship between $A L K$ copy number gain/amplification and sensitivity to crizotinib treatment is not established, as recommended by most studies, cases with $A L K$ amplification should be further investigated [17,18,73-76]. It is important to emphasize that the definition of $A L K$ copy number gain/amplification varies among these studies, and validated cutoff values need to be established in each individual laboratory.

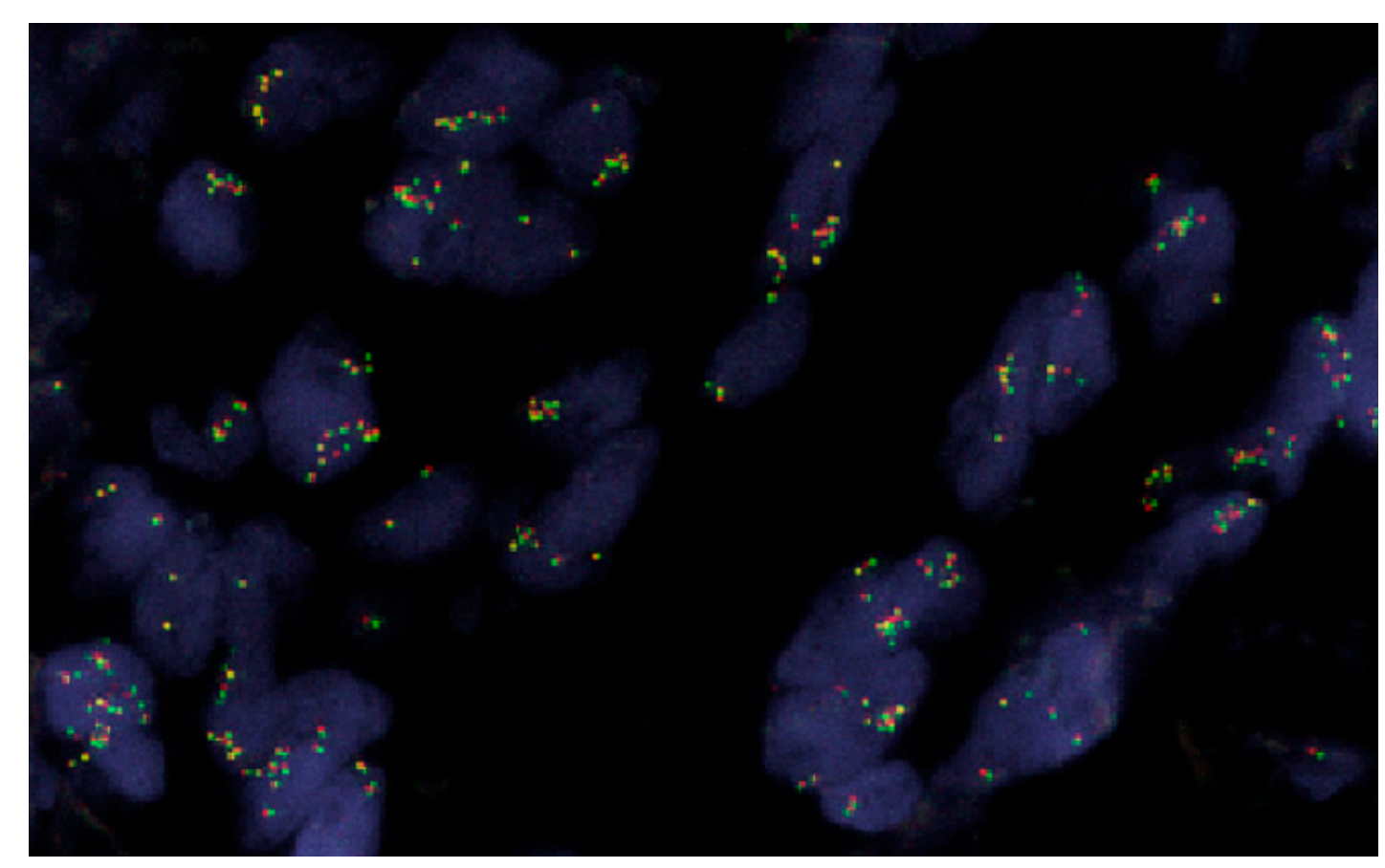

Figure 3. An example of $A L K$ amplification in a lung adenocarcinoma case. The majority of tumor cells showed 6 to 20 copies of $A L K$ gene or cluster ALK signals (60x).

\subsubsection{Co-Existent Driver Mutations}

Others have reported in earlier studies that $A L K$ rearrangements are mutually exclusive with other driver mutations, e.g., mutations in EGFR or KRAS, ROS1 rearrangement, RET rearrangement or MET amplification [14,15,77]. Patients with one of these mutations might be excluded for $A L K$ rearrangement testing at that time $[16,17,68,78]$. Recently, cases with coexistence of two or more driver mutations including $A L K$ rearrangement have been reported [79-81], in part attributable to detection of multiple biomarkers from the same specimen and/or utilization of technologies, such as NGS, which detects multiple hotspots simultaneously. Therefore, a comprehensive genomic testing of many known driver mutations in NSCLC specimens, including at least $A L K, R O S 1, R E T, M E T, E R B B 2, B R A F$ and KRAS genes, has been proposed if NGS based methodology is performed [68]. It seems likely that more cases with co-existing driver mutations will be identified. However, it remains unknown whether the co-existing driver mutations are from the same tumor cells, for which one targeted agent may be applied, or from different tumor cells representing a type of intratumoral heterogeneity, for which various specific agents for different targets may be necessarily applied simultaneously or one after another. 
In summary, the FDA-approved Vysis Break Apart ALK FISH probe has served as the "gold standard" for assessment of ALK status in NSCLC specimens during the past decade and is still widely used in clinical laboratories in the United States. In this concise review, we have discussed practical issues related to several clinically relevant technical aspects, including: the pros and cons of the unique two-step (50- to 100-cell) analysis approach; the preset cutoff value of $\geq 15 \%$ for a positive result; technical causes and biology of discordant results obtained by different methods; and incidental findings during ALK FISH testing [68].

\section{Conclusions}

Both "borderline negative" and "borderline positive" ALK FISH results can be a huge challenge to correctly interpret. For these clinical scenarios, a reflex test should be available. Cases with discordant results obtained by different methods, e.g., ALK FISH and ALK IHC, should be further investigated, e.g. by NGS-based method(s). A test algorithm is strongly recommended for clinical laboratories where several tests for ALK status in NSCLC specimens are offered and/or available.

Author Contributions: Drafted, Z.T. and L.W.; Reviewed and edited, G.T. and L.J.M.; Replied to reviewers' comments and revised, Z.T.

Funding: This research received no external funding.

Conflicts of Interest: The authors declare no conflicts of interest.

\section{References}

1. Lung and Brunchus; American Cancer Society Inc.: Atlanta, GA, USA, 2019; Volume 2019.

2. Bray, F.; Ferlay, J.; Soerjomataram, I.; Siegel, R.L.; Torre, L.A.; Jemal, A. Global cancer statistics 2018: GLOBOCAN estimates of incidence and mortality worldwide for 36 cancers in 185 countries. CA: A Cancer J. Clin. 2018, 68, 394-424. [CrossRef]

3. Ferlay, J.; Colombet, M.; Soerjomataram, I.; Mathers, C.; Parkin, D.M.; Pineros, M.; Znaor, A.; Bray, F. Estimating the global cancer incidence and mortality in 2018: GLOBOCAN sources and methods. Int. J. Cancer 2019, 144, 1941-1953. [CrossRef]

4. Vargas, A.J.; Harris, C.C. Biomarker development in the precision medicine era: Lung cancer as a case study. Nat. Rev. Cancer 2016, 16, 525-537. [CrossRef]

5. Barrows, S.M.; Wright, K.; Copley-Merriman, C.; Kaye, J.A.; Chioda, M.; Wiltshire, R.; Torgersen, K.M.; Masters, E.T. Systematic review of sequencing of ALK inhibitors in ALK-positive non-small-cell lung cancer. Lung Cancer (Auckl. N.Z.) 2019, 10, 11-20. [CrossRef]

6. Remon, J.; Ahn, M.J.; Girard, N.; Johnson, M.; Kim, D.W.; Lopes, G.; Pillai, R.N.; Solomon, B.; Villacampa, G.; Zhou, Q. Advanced Stage Non-Small Cell Lung Cancer: Advances in Thoracic Oncology 2018. J. Thorac. Oncol. 2019. [CrossRef]

7. Recondo, G.; Facchinetti, F.; Olaussen, K.A.; Besse, B.; Friboulet, L. Making the first move in EGFR-driven or ALK-driven NSCLC: First-generation or next-generation TKI? Nat. Rev. Clin. Oncol. 2018, 15, 694-708. [CrossRef]

8. Vysis ALK Break ApartFISH Probe Kit. 2011. Available online: https:/www.molecular.abbott/sal/en-us/ staticAssets/ALK-US-CE-Clinical-PI_R3_mw001_3060.pdf (accessed on 12 April 2019).

9. Abbott Molecular, Inc. Vysis ALK Break Apart FISH Probe Kit. Summary of Safety and Effectiveness Data (SSED). Available online: http://www.accessdata.fda.gov/cdrh_docs/pdf11/P110012b.pdf (accessed on 12 April 2019).

10. Liehr, T.; Ziegler, M. Rapid prenatal diagnostics in the interphase nucleus: Procedure and cut-off rates. J. Histochem. Cytochem. 2005, 53, 289-291. [CrossRef]

11. Mascarello, J.T.; Hirsch, B.; Kearney, H.M.; Ketterling, R.P.; Olson, S.B.; Quigley, D.I.; Rao, K.W.; Tepperberg, J.H.; Tsuchiya, K.D.; Wiktor, A.E. Section E9 of the American College of Medical Genetics technical standards and guidelines: Fluorescence in situ hybridization. Genet. Med. 2011, 13, 667-675. [CrossRef] 
12. Test and Technology Transfer Committee. Technical and clinical assessment of fluorescence in situ hybridization: An ACMG/ASHG position statement. I. Technical considerations. Genet. Med. 2000, 2, 356-361. [CrossRef]

13. Wolff, D.J.; Bagg, A.; Cooley, L.D.; Dewald, G.W.; Hirsch, B.A.; Jacky, P.B.; Rao, K.W.; Rao, P.N. Guidance for fluorescence in situ hybridization testing in hematologic disorders. J. Mol. Diagn. 2007, 9, $134-143$. [CrossRef]

14. Kwak, E.L.; Bang, Y.J.; Camidge, D.R.; Shaw, A.T.; Solomon, B.; Maki, R.G.; Ou, S.H.; Dezube, B.J.; Janne, P.A.; Costa, D.B.; et al. Anaplastic lymphoma kinase inhibition in non-small-cell lung cancer. N. Engl. J. Med. 2010, 363, 1693-1703. [CrossRef]

15. Camidge, D.R.; Bang, Y.J.; Kwak, E.L.; Iafrate, A.J.; Varella-Garcia, M.; Fox, S.B.; Riely, G.J.; Solomon, B.; Ou, S.H.; Kim, D.W.; et al. Activity and safety of crizotinib in patients with ALK-positive non-small-cell lung cancer: Updated results from a phase 1 study. Lancet. Oncol. 2012, 13, 1011-1019. [CrossRef]

16. Camidge, D.R.; Kono, S.A.; Flacco, A.; Tan, A.C.; Doebele, R.C.; Zhou, Q.; Crino, L.; Franklin, W.A.; Varella-Garcia, M. Optimizing the detection of lung cancer patients harboring anaplastic lymphoma kinase (ALK) gene rearrangements potentially suitable for ALK inhibitor treatment. Clin. Cancer Res. 2010, 16, 5581-5590. [CrossRef]

17. Camidge, D.R.; Theodoro, M.; Maxson, D.A.; Skokan, M.; O’Brien, T.; Lu, X.; Doebele, R.C.; Baron, A.E.; Varella-Garcia, M. Correlations between the percentage of tumor cells showing an anaplastic lymphoma kinase (ALK) gene rearrangement, ALK signal copy number, and response to crizotinib therapy in ALK fluorescence in situ hybridization-positive nonsmall cell lung cancer. Cancer 2012, 118, 4486-4494. [CrossRef]

18. Camidge, D.R.; Skokan, M.; Kiatsimkul, P.; Helfrich, B.; Lu, X.; Baron, A.E.; Schulte, N.; Maxson, D.; Aisner, D.L.; Franklin, W.A.; et al. Native and rearranged ALK copy number and rearranged cell count in non-small cell lung cancer: Implications for ALK inhibitor therapy. Cancer 2013, 119, 3968-3975. [CrossRef]

19. Soria, J.C.; Ho, S.N.; Varella-Garcia, M.; Iafrate, A.J.; Solomon, B.J.; Shaw, A.T.; Blackhall, F.; Mok, T.S.; $\mathrm{Wu}$, Y.L.; Pestova, K.; et al. Correlation of extent of ALK FISH positivity and crizotinib efficacy in three prospective studies of ALK-positive patients with non-small-cell lung cancer. Ann. Oncol. 2018, 29, 1964-1971. [CrossRef]

20. Toruner, G.; Tang, Z.; Tang, G.; Medeiros, J.; Hu, S. Clonal size of ALK rearrangements detected by FISH is associated with the duration of progression free survival in metastatic lung cancer with ALK inhibitors. Cancer Genet. 2019, 233, S20. [CrossRef]

21. Shaw, A.T.; Yeap, B.Y.; Mino-Kenudson, M.; Digumarthy, S.R.; Costa, D.B.; Heist, R.S.; Solomon, B.; Stubbs, H.; Admane, S.; McDermott, U.; et al. Clinical features and outcome of patients with non-small-cell lung cancer who harbor EML4-ALK. J. Clin. Oncol. 2009, 27, 4247-4253. [CrossRef]

22. Rodig, S.J.; Mino-Kenudson, M.; Dacic, S.; Yeap, B.Y.; Shaw, A.; Barletta, J.A.; Stubbs, H.; Law, K.; Lindeman, N.; Mark, E.; et al. Unique clinicopathologic features characterize ALK-rearranged lung adenocarcinoma in the western population. Clin. Cancer Res. 2009, 15, 5216-5223. [CrossRef]

23. Martin, V.; Bernasconi, B.; Merlo, E.; Balzarini, P.; Vermi, W.; Riva, A.; Chiaravalli, A.M.; Frattini, M.; Sahnane, N.; Facchetti, F.; et al. ALK testing in lung adenocarcinoma: Technical aspects to improve FISH evaluation in daily practice. J. Thorac. Oncol. 2015, 10, 595-602. [CrossRef]

24. Yi, E.S.; Boland, J.M.; Maleszewski, J.J.; Roden, A.C.; Oliveira, A.M.; Aubry, M.C.; Erickson-Johnson, M.R.; Caron, B.L.; Li, Y.; Tang, H.; et al. Correlation of IHC and FISH for ALK gene rearrangement in non-small cell lung carcinoma: IHC score algorithm for FISH. J. Thorac. Oncol. 2011, 6, 459-465. [CrossRef]

25. Sun, J.M.; Choi, Y.L.; Won, J.K.; Hirsch, F.R.; Ahn, J.S.; Ahn, M.J.; Park, K. A dramatic response to crizotinib in a non-small-cell lung cancer patient with IHC-positive and FISH-negative ALK. J. Thorac. Oncol. 2012, 7, e36-e38. [CrossRef]

26. Bavieri, M.; Tiseo, M.; Lantuejoul, S.; McLeer-Florin, A.; Lasagni, A.; Fantini, R.; Rossi, G. Fishing for ALK with immunohistochemistry may predict response to crizotinib. Tumori 2013, 99, e229-e232. [CrossRef]

27. Lee, J.A.; Bubendorf, L.; Stahel, R.; Peters, S. Testing for anaplastic lymphoma kinase rearrangement to target crizotinib therapy: Oncology, pathology and health economic perspectives. Expert Rev. Anticancer Ther. 2013, 13, 625-636. [CrossRef] 
28. Laffert, M.V.; Warth, A.; Penzel, R.; Schirmacher, P.; Jonigk, D.; Kreipe, H.; Schildhaus, H.U.; Merkelbach-Bruse, S.; Buttner, R.; Reu, S.; et al. Anaplastic lymphoma kinase (ALK) gene rearrangement in non-small cell lung cancer (NSCLC): Results of a multi-centre ALK-testing. Lung Cancer (Amst. Neth.) 2013, 81, 200-206. [CrossRef]

29. Blackhall, F.; Ross Camidge, D.; Shaw, A.T.; Soria, J.C.; Solomon, B.J.; Mok, T.; Hirsh, V.; Janne, P.A.; Shi, Y.; Yang, P.C.; et al. Final results of the large-scale multinational trial PROFILE 1005: Efficacy and safety of crizotinib in previously treated patients with advanced/metastatic ALK-positive non-small-cell lung cancer. ESMO Open 2017, 2, e000219. [CrossRef]

30. Shaw, A.T.; Kim, D.W.; Nakagawa, K.; Seto, T.; Crino, L.; Ahn, M.J.; De Pas, T.; Besse, B.; Solomon, B.J.; Blackhall, F.; et al. Crizotinib versus chemotherapy in advanced ALK-positive lung cancer. N. Engl. J. Med. 2013, 368, 2385-2394. [CrossRef]

31. Solomon, B.J.; Mok, T.; Kim, D.W.; Wu, Y.L.; Nakagawa, K.; Mekhail, T.; Felip, E.; Cappuzzo, F.; Paolini, J.; Usari, T.; et al. First-line crizotinib versus chemotherapy in ALK-positive lung cancer. N. Engl. J. Med. 2014, 371, 2167-2177. [CrossRef]

32. Solomon, B.J.; Kim, D.W.; Wu, Y.L.; Nakagawa, K.; Mekhail, T.; Felip, E.; Cappuzzo, F.; Paolini, J.; Usari, T.; Tang, Y; et al. Final Overall Survival Analysis From a Study Comparing First-Line Crizotinib Versus Chemotherapy in ALK-Mutation-Positive Non-Small-Cell Lung Cancer. J. Clin. Oncol. 2018, 36, 2251-2258. [CrossRef]

33. Cabillic, F.; Gros, A.; Dugay, F.; Begueret, H.; Mesturoux, L.; Chiforeanu, D.C.; Dufrenot, L.; Jauffret, V.; Dachary, D.; Corre, R.; et al. Parallel FISH and immunohistochemical studies of ALK status in 3244 non-small-cell lung cancers reveal major discordances. J. Thorac. Oncol. 2014, 9, 295-306. [CrossRef]

34. Ilie, M.I.; Bence, C.; Hofman, V.; Long-Mira, E.; Butori, C.; Bouhlel, L.; Lalvee, S.; Mouroux, J.; Poudenx, M.; Otto, J.; et al. Discrepancies between FISH and immunohistochemistry for assessment of the ALK status are associated with ALK 'borderline'-positive rearrangements or a high copy number: A potential major issue for anti-ALK therapeutic strategies. Ann. Oncol. 2015, 26, 238-244. [CrossRef]

35. Von Laffert, M.; Stenzinger, A.; Hummel, M.; Weichert, W.; Lenze, D.; Warth, A.; Penzel, R.; Herbst, H.; Kellner, U.; Jurmeister, P.; et al. ALK-FISH borderline cases in non-small cell lung cancer: Implications for diagnostics and clinical decision making. Lung Cancer (Amst. Neth.) 2015, 90, 465-471. [CrossRef]

36. Jokoji, R.; Yamasaki, T.; Minami, S.; Komuta, K.; Sakamaki, Y.; Takeuchi, K.; Tsujimoto, M. Combination of morphological feature analysis and immunohistochemistry is useful for screening of EML4-ALK-positive lung adenocarcinoma. J. Clin. Pathol. 2010, 63, 1066-1070. [CrossRef]

37. Paik, J.H.; Choe, G.; Kim, H.; Choe, J.Y.; Lee, H.J.; Lee, C.T.; Lee, J.S.; Jheon, S.; Chung, J.H. Screening of anaplastic lymphoma kinase rearrangement by immunohistochemistry in non-small cell lung cancer: Correlation with fluorescence in situ hybridization. J. Thorac. Oncol. 2011, 6, 466-472. [CrossRef]

38. Just, P.A.; Cazes, A.; Audebourg, A.; Cessot, A.; Pallier, K.; Danel, C.; Vacher-Lavenu, M.C.; Laurent-Puig, P.; Terris, B.; Blons, H. Histologic subtypes, immunohistochemistry, FISH or molecular screening for the accurate diagnosis of ALK-rearrangement in lung cancer: A comprehensive study of Caucasian non-smokers. Lung Cancer (Amst. Neth.) 2012, 76, 309-315. [CrossRef]

39. McLeer-Florin, A.; Moro-Sibilot, D.; Melis, A.; Salameire, D.; Lefebvre, C.; Ceccaldi, F.; de Fraipont, F.; Brambilla, E.; Lantuejoul, S. Dual IHC and FISH testing for ALK gene rearrangement in lung adenocarcinomas in a routine practice: A French study. J. Thorac. Oncol. 2012, 7, 348-354. [CrossRef]

40. Park, H.S.; Lee, J.K.; Kim, D.W.; Kulig, K.; Kim, T.M.; Lee, S.H.; Jeon, Y.K.; Chung, D.H.; Heo, D.S. Immunohistochemical screening for anaplastic lymphoma kinase (ALK) rearrangement in advanced non-small cell lung cancer patients. Lung Cancer (Amst. Neth.) 2012, 77, 288-292. [CrossRef]

41. Conklin, C.M.; Craddock, K.J.; Have, C.; Laskin, J.; Couture, C.; Ionescu, D.N. Immunohistochemistry is a reliable screening tool for identification of ALK rearrangement in non-small-cell lung carcinoma and is antibody dependent. J. Thorac. Oncol. 2013, 8, 45-51. [CrossRef]

42. Selinger, C.I.; Rogers, T.M.; Russell, P.A.; O’Toole, S.; Yip, P.; Wright, G.M.; Wainer, Z.; Horvath, L.G.; Boyer, M.; McCaughan, B.; et al. Testing for ALK rearrangement in lung adenocarcinoma: A multicenter comparison of immunohistochemistry and fluorescent in situ hybridization. Mod. Pathol. 2013, 26, 1545-1553. [CrossRef] 
43. Conde, E.; Suarez-Gauthier, A.; Benito, A.; Garrido, P.; Garcia-Campelo, R.; Biscuola, M.; Paz-Ares, L.; Hardisson, D.; de Castro, J.; Camacho, M.C.; et al. Accurate identification of ALK positive lung carcinoma patients: Novel FDA-cleared automated fluorescence in situ hybridization scanning system and ultrasensitive immunohistochemistry. PLoS ONE 2014, 9, e107200. [CrossRef]

44. Wynes, M.W.; Sholl, L.M.; Dietel, M.; Schuuring, E.; Tsao, M.S.; Yatabe, Y.; Tubbs, R.R.; Hirsch, F.R. An international interpretation study using the ALK IHC antibody D5F3 and a sensitive detection kit demonstrates high concordance between ALK IHC and ALK FISH and between evaluators. J. Thorac. Oncol. 2014, 9, 631-638. [CrossRef]

45. Ventane ALK (D5F3) CDX Assay. Available online: https://www.accessdata.fda.gov/cdrh_docs/pdf14/ p140025c.pdf (accessed on 12 April 2019).

46. Conde, E.; Hernandez, S.; Prieto, M.; Martinez, R.; Lopez-Rios, F. Profile of Ventana ALK (D5F3) companion diagnostic assay for non-small-cell lung carcinomas. Expert Rev. Mol. Diagn. 2016, 16, 707-713. [CrossRef]

47. Soda, M.; Isobe, K.; Inoue, A.; Maemondo, M.; Oizumi, S.; Fujita, Y.; Gemma, A.; Yamashita, Y.; Ueno, T.; Takeuchi, K.; et al. A prospective PCR-based screening for the EML4-ALK oncogene in non-small cell lung cancer. Clin. Cancer Res. 2012, 18, 5682-5689. [CrossRef]

48. Li, Y.; Pan, Y.; Wang, R.; Sun, Y.; Hu, H.; Shen, X.; Lu, Y.; Shen, L.; Zhu, X.; Chen, H. ALK-rearranged lung cancer in Chinese: A comprehensive assessment of clinicopathology, IHC, FISH and RT-PCR. PLoS ONE 2013, 8, e69016. [CrossRef]

49. Wu, Y.C.; Chang, I.C.; Wang, C.L.; Chen, T.D.; Chen, Y.T.; Liu, H.P.; Chu, Y.; Chiu, Y.T.; Wu, T.H.; Chou, L.H.; et al. Comparison of IHC, FISH and RT-PCR methods for detection of ALK rearrangements in 312 non-small cell lung cancer patients in Taiwan. PLoS ONE 2013, 8, e70839. [CrossRef]

50. Nakamichi, S.; Seike, M.; Miyanaga, A.; Chiba, M.; Matsuda, K.; Kobayashi, K.; Takahashi, A.; Takeuchi, S.; Minegishi, Y.; Kubota, K.; et al. RT-PCR for Detecting ALK Translocations in Cytology Samples from Lung Cancer Patients. Anticancer Res. 2017, 37, 3295-3299. [CrossRef]

51. Abel, H.J.; Al-Kateb, H.; Cottrell, C.E.; Bredemeyer, A.J.; Pritchard, C.C.; Grossmann, A.H.; Wallander, M.L.; Pfeifer, J.D.; Lockwood, C.M.; Duncavage, E.J. Detection of gene rearrangements in targeted clinical next-generation sequencing. J. Mol. Diagn. 2014, 16, 405-417. [CrossRef]

52. Pekar-Zlotin, M.; Hirsch, F.R.; Soussan-Gutman, L.; Ilouze, M.; Dvir, A.; Boyle, T.; Wynes, M.; Miller, V.A.; Lipson, D.; Palmer, G.A.; et al. Fluorescence in situ hybridization, immunohistochemistry, and next-generation sequencing for detection of EML4-ALK rearrangement in lung cancer. Oncologist 2015, 20, 316-322. [CrossRef]

53. Ali, S.M.; Hensing, T.; Schrock, A.B.; Allen, J.; Sanford, E.; Gowen, K.; Kulkarni, A.; He, J.; Suh, J.H.; Lipson, D.; et al. Comprehensive Genomic Profiling Identifies a Subset of Crizotinib-Responsive ALK-Rearranged Non-Small Cell Lung Cancer Not Detected by Fluorescence In Situ Hybridization. Oncologist 2016, 21, 762-770. [CrossRef]

54. Volckmar, A.L.; Endris, V.; Bozorgmehr, F.; Lier, C.; Porcel, C.; Kirchner, M.; Leichsenring, J.; Penzel, R.; Thomas, M.; Schirmacher, P.; et al. Next-generation sequencing facilitates detection of the classic E13-A20 EML4-ALK fusion in an ALK-FISH/IHC inconclusive biopsy of a stage IV lung cancer patient: A case report. Diagn. Pathol. 2016, 11, 133. [CrossRef]

55. Jang, J.S.; Wang, X.; Vedell, P.T.; Wen, J.; Zhang, J.; Ellison, D.W.; Evans, J.M.; Johnson, S.H.; Yang, P.; Sukov, W.R.; et al. Custom Gene Capture and Next-Generation Sequencing to Resolve Discordant ALK Status by FISH and IHC in Lung Adenocarcinoma. J. Thorac. Oncol. 2016, 11, 1891-1900. [CrossRef]

56. McLeer-Florin, A.; Duruisseaux, M.; Pinsolle, J.; Dubourd, S.; Mondet, J.; Phillips Houlbracq, M.; Magnat, N.; Faure, J.; Chatagnon, A.; de Fraipont, F.; et al. ALK fusion variants detection by targeted RNA-next generation sequencing and clinical responses to crizotinib in ALK-positive non-small cell lung cancer. Lung Cancer (Amst. Neth.) 2018, 116, 15-24. [CrossRef]

57. Sequist, L.V.; Heist, R.S.; Shaw, A.T.; Fidias, P.; Rosovsky, R.; Temel, J.S.; Lennes, I.T.; Digumarthy, S.; Waltman, B.A.; Bast, E.; et al. Implementing multiplexed genotyping of non-small-cell lung cancers into routine clinical practice. Ann. Oncol. 2011, 22, 2616-2624. [CrossRef]

58. Wang, Q.; Yang, X.; He, Y.; Ma, Q.; Lin, L.; Fu, P.; Xiao, H. Droplet Digital PCR for Absolute Quantification of EML4-ALK Gene Rearrangement in Lung Adenocarcinoma. J. Mol. Diagn. 2015, 17, 515-520. [CrossRef]

59. Lund, H.L.; Hughesman, C.B.; Fakhfakh, K.; McNeil, K.; Clemens, S.; Hocken, K.; Pettersson, R.; Karsan, A.; Foster, L.J.; Haynes, C. Initial Diagnosis of ALK-Positive Non-Small-Cell Lung Cancer Based on Analysis of ALK Status Utilizing Droplet Digital PCR. Anal. Chem. 2016, 88, 4879-4885. [CrossRef] 
60. Evangelista, A.F.; Zanon, M.F.; Carloni, A.C.; de Paula, F.E.; Morini, M.A.; Ferreira-Neto, M.; Soares, I.C.; Miziara, J.E.; de Marchi, P.; Scapulatempo-Neto, C.; et al. Detection of ALK fusion transcripts in FFPE lung cancer samples by NanoString technology. BMC Pulm. Med. 2017, 17, 86. [CrossRef]

61. Rogers, T.M.; Arnau, G.M.; Ryland, G.L.; Huang, S.; Lira, M.E.; Emmanuel, Y.; Perez, O.D.; Irwin, D.; Fellowes, A.P.; Wong, S.Q.; et al. Multiplexed transcriptome analysis to detect ALK, ROS1 and RET rearrangements in lung cancer. Sci. Rep. 2017, 7, 42259. [CrossRef]

62. von Laffert, M.; Warth, A.; Penzel, R.; Schirmacher, P.; Kerr, K.M.; Elmberger, G.; Schildhaus, H.U.; Buttner, R.; Lopez-Rios, F.; Reu, S.; et al. Multicenter immunohistochemical ALK-testing of non-small-cell lung cancer shows high concordance after harmonization of techniques and interpretation criteria. J. Thorac. Oncol. 2014, 9, 1685-1692. [CrossRef]

63. Mattsson, J.S.; Brunnstrom, H.; Jabs, V.; Edlund, K.; Jirstrom, K.; Mindus, S.; la Fleur, L.; Ponten, F.; Karlsson, M.G.; Karlsson, C.; et al. Inconsistent results in the analysis of ALK rearrangements in non-small cell lung cancer. BMC Cancer 2016, 16, 603. [CrossRef]

64. Gao, X.; Sholl, L.M.; Nishino, M.; Heng, J.C.; Janne, P.A.; Oxnard, G.R. Clinical Implications of Variant ALK FISH Rearrangement Patterns. J. Thorac. Oncol. 2015, 10, 1648-1652. [CrossRef]

65. Wiesner, T.; Lee, W.; Obenauf, A.C.; Ran, L.; Murali, R.; Zhang, Q.F.; Wong, E.W.; Hu, W.; Scott, S.N.; Shah, R.H.; et al. Alternative transcription initiation leads to expression of a novel ALK isoform in cancer. Nature 2015, 526, 453-457. [CrossRef]

66. Selinger, C.; Cooper, W.; Lum, T.; McNeil, C.; Morey, A.; Waring, P.; Amanuel, B.; Millward, M.; Peverall, J.; Van Vliet, C.; et al. Equivocal ALK fluorescence in-situ hybridization (FISH) cases may benefit from ancillary ALK FISH probe testing. Histopathology 2015, 67, 654-663. [CrossRef]

67. Vollbrecht, C.; Lenze, D.; Hummel, M.; Lehmann, A.; Moebs, M.; Frost, N.; Jurmeister, P.; Schweizer, L.; Kellner, U.; Dietel, M.; et al. RNA-based analysis of ALK fusions in non-small cell lung cancer cases showing IHC/FISH discordance. BMC Cancer 2018, 18, 1158. [CrossRef]

68. Lindeman, N.I.; Cagle, P.T.; Aisner, D.L.; Arcila, M.E.; Beasley, M.B.; Bernicker, E.H.; Colasacco, C.; Dacic, S.; Hirsch, F.R.; Kerr, K.; et al. Updated Molecular Testing Guideline for the Selection of Lung Cancer Patients for Treatment With Targeted Tyrosine Kinase Inhibitors: Guideline From the College of American Pathologists, the International Association for the Study of Lung Cancer, and the Association for Molecular Pathology. Arch. Pathol. Lab. Med. 2018, 142, 321-346. [CrossRef]

69. Marchetti, A.; Pace, M.V.; Di Lorito, A.; Canarecci, S.; Felicioni, L.; D'Antuono, T.; Liberatore, M.; Filice, G.; Guetti, L.; Mucilli, F.; et al. Validation of a new algorithm for a quick and easy RT-PCR-based ALK test in a large series of lung adenocarcinomas: Comparison with FISH, immunohistochemistry and next generation sequencing assays. Lung Cancer (Amst. Neth.) 2016, 99, 11-16. [CrossRef]

70. Wang, R.; Pan, Y.; Li, C.; Hu, H.; Zhang, Y.; Li, H.; Luo, X.; Zhang, J.; Fang, Z.; Li, Y.; et al. The use of quantitative real-time reverse transcriptase PCR for $5^{\prime}$ and $3^{\prime}$ portions of ALK transcripts to detect ALK rearrangements in lung cancers. Clin. Cancer Res. 2012, 18, 4725-4732. [CrossRef]

71. Takamochi, K.; Takeuchi, K.; Hayashi, T.; Oh, S.; Suzuki, K. A rational diagnostic algorithm for the identification of ALK rearrangement in lung cancer: A comprehensive study of surgically treated Japanese patients. PLoS ONE 2013, 8, e69794. [CrossRef]

72. Sholl, L.M.; Weremowicz, S.; Gray, S.W.; Wong, K.K.; Chirieac, L.R.; Lindeman, N.I.; Hornick, J.L. Combined use of ALK immunohistochemistry and FISH for optimal detection of ALK-rearranged lung adenocarcinomas. J. Thorac. Oncol. 2013, 8, 322-328. [CrossRef]

73. Zito Marino, F.; Rocco, G.; Morabito, A.; Mignogna, C.; Intartaglia, M.; Liguori, G.; Botti, G.; Franco, R. A new look at the ALK gene in cancer: Copy number gain and amplification. Expert Rev. Anticancer Ther. 2016, 16, 493-502. [CrossRef]

74. Salido, M.; Pijuan, L.; Martinez-Aviles, L.; Galvan, A.B.; Canadas, I.; Rovira, A.; Zanui, M.; Martinez, A.; Longaron, R.; Sole, F.; et al. Increased ALK gene copy number and amplification are frequent in non-small cell lung cancer. J. Thorac. Oncol. 2011, 6, 21-27. [CrossRef]

75. Preusser, M.; Berghoff, A.S.; Ilhan-Mutlu, A.; Magerle, M.; Dinhof, C.; Widhalm, G.; Dieckmann, K.; Marosi, C.; Wohrer, A.; Hackl, M.; et al. ALK gene translocations and amplifications in brain metastases of non-small cell lung cancer. Lung Cancer (Amst. Neth.) 2013, 80, 278-283. [CrossRef] 
76. Peretti, U.; Ferrara, R.; Pilotto, S.; Kinspergher, S.; Caccese, M.; Santo, A.; Brunelli, M.; Calio, A.; Carbognin, L.; Sperduti, I.; et al. ALK gene copy number gains in non-small-cell lung cancer: Prognostic impact and clinico-pathological correlations. Respir. Res. 2016, 17, 105. [CrossRef]

77. Gainor, J.F.; Varghese, A.M.; Ou, S.H.; Kabraji, S.; Awad, M.M.; Katayama, R.; Pawlak, A.; Mino-Kenudson, M.; Yeap, B.Y.; Riely, G.J.; et al. ALK rearrangements are mutually exclusive with mutations in EGFR or KRAS: An analysis of 1,683 patients with non-small cell lung cancer. Clin. Cancer Res. 2013, 19, 4273-4281. [CrossRef]

78. Mescam-Mancini, L.; Lantuejoul, S.; Moro-Sibilot, D.; Rouquette, I.; Souquet, P.J.; Audigier-Valette, C.; Sabourin, J.C.; Decroisette, C.; Sakhri, L.; Brambilla, E.; et al. On the relevance of a testing algorithm for the detection of ROS1-rearranged lung adenocarcinomas. Lung Cancer (Amst. Neth.) 2014, 83, 168-173. [CrossRef]

79. Lou, N.N.; Zhang, X.C.; Chen, H.J.; Zhou, Q.; Yan, L.X.; Xie, Z.; Su, J.; Chen, Z.H.; Tu, H.Y.; Yan, H.H.; et al. Clinical outcomes of advanced non-small-cell lung cancer patients with EGFR mutation, ALK rearrangement and EGFR/ALK co-alterations. Oncotarget 2016, 7, 65185-65195. [CrossRef]

80. Tang, Z.; Zhang, J.; Lu, X.; Wang, W.; Chen, H.; Robinson, M.K.; Cheng, J.; Tang, G.; Medeiros, L.J. Coexistent genetic alterations involving ALK, RET, ROS1 or MET in 15 cases of lung adenocarcinoma. Mod. Pathol. 2018, 31, 307-312. [CrossRef]

81. Sweis, R.F.; Thomas, S.; Bank, B.; Fishkin, P.; Mooney, C.; Salgia, R. Concurrent EGFR Mutation and ALK Translocation in Non-Small Cell Lung Cancer. Cureus 2016, 8, e513. [CrossRef]

(C) 2019 by the authors. Licensee MDPI, Basel, Switzerland. This article is an open access article distributed under the terms and conditions of the Creative Commons Attribution (CC BY) license (http://creativecommons.org/licenses/by/4.0/). 